\title{
PENGARUH TINGKAT PENGETAHUAN AGAMA TERHADAP PERSEPSI MAHASISWA PADA GERAKAN RADIKALISME BERBASIS AGAMA (STUDI PADA MAHASISWA UIN RADEN INTAN LAMPUNG)
}

\author{
Imam Syafei \\ imams@radenintan.ac.id \\ Universitas Islam Negeri Raden Intan Lampung
}

\begin{abstract}
The main objective in this study was to determine the effect of the level of religious knowledge on student perceptions of religious-based radicalism movements. This type of research is survey research using quantitative research methods. The population is fifth semester students at Raden Intan Lampung State Islamic University 2017/2018 academic year with a sample of 295 students. The technique of collecting data uses questionnaires and documents. The data that has been obtained is then analyzed using a simple linear regression test. The conclusion of the study is that the research hypothesis is not accepted, so the level of religious knowledge does not have a significant effect on student perceptions of religious-based radicalism. The magnitude of the influence of religious knowledge on student perceptions of religious-based radicalism is only $1.7 \%$ which is categorized as very weak influence.
\end{abstract}

Keywords: religious knowledge, student perceptions, religious-based radicalism movements.

\begin{abstract}
Abstrak
Tujuan utama dalam penelitian ini adalah untuk mengetahui pengaruh tingkat pengetahuan agama terhadap persepsi mahasiswa pada gerakan radikalisme berbasis agama. Jenis penelitian ini adalah penelitian survei dengan menggunakan metode penelitian kuantitatif. Populasinya adalah mahasiswa semester V di Universitas Islam Negeri Raden Intan Lampung tahun pelajaran 2017/2018 dengan jumlah sampel 295 mahasiswa. Teknik pengumpulan data menggunakan angket dan dokumen. Data yang telah diperoleh kemudian dianalisis dengan menggunakan uji regresi linier sederhana. Kesimpulan penelitian adalah hipotesis penelitian tidak diterima, sehingga tingkat pengetahuan agama tidak memiliki pengaruh yang signifikan terhadap persepsi mahasiswa pada gerakan radikalisme berbasis agama. Besarnya pengaruh pengetahuan agama terhadap persepsi mahasiswa pada gerakan radikalisme berbasis agama hanya $1,7 \%$ yang dikategorikan pengaruhnya sangat lemah.
\end{abstract}

Kata Kunci: pengetahuan agama, persepsi mahasiswa, gerakan radikalisme berbasis agama

\section{PENDAHULUAN}

Menurut (Azra, 1999), agama merupakan lahan empuk untuk menjadi crying banner dalam melakukan tindakan anarkis (radikalisme-Penulis), yang juga sama-sama didasari pada pembacaan dan konstruksi tekstualitas yang ada dalam agama itu sendiri. Demikian juga menurut (Crawford, 2001), dalam relasinya dengan politik, agama dengan mudah terseret dalam kancah radikalisme dengan dipolitisasinya agama sebagai 
sumber radikalisme terbuka, yang sebenarnya lebih didasari oleh melemahnya sistem dan institusi politik yang ada.

Proses yang terjadi dalam radikalisme adalah radikalisasi, yang didefinisikan sebagai proses personal di mana individu mengadopsi idealisme dan aspirasi politik, sosial, atau agama secara ekstrim, dimana dalam pencapaian tujuannya membenarkan penggunaan kekerasan tanpa pandang bulu, sehingga mempersiapkan dan memotivasi seseorang untuk mencapai perilaku kekerasan (Wilner \& Dubouloz, 2009).

Radikalisme Islam dinisbatkan sebagai gerakan yang berpandangan kolot dan sering menggunakan kekerasan dalam mengajarkan serta mempertahankan keyakinan mereka. Alhasil Islam yang tadinya merupakan agama penjamin keselamatan bagi semesta alam menjadi agama yang terkesan "garang", simpatisan gerakan radikal Islam pun terkesan sangar dan beringas di mata masyarakat. Sungguh hal itu sangat disayangkan, masyarakat Indonesia yang sebagian besar muslim yang terkenal ramah di mata dunia, kini sebagian menjadi masyarakat muslim Indonesia yang beringas dan mudah menyulut api kerusuhan (Nadia, 2012).

Gerakan radikalisme khususnya radikalisme agama merupakan ancaman tidak hanya bagi multikultiral tetapi juga ancaman bagi Negara Kesatuan Rebulik Indonesia (NKRI). Berkaitan dengan bahaya tersebut, Presiden Susilo Bambang Yudoyono (SBY) dalam rapat Musrenbangnas 28 April 2011 dihadiri semua Menteri Kabinet Indonesia Bersatu II, Gubernur, Bupati/Wali Kota seluruh Indonesia menegaskan bahwa "Terorisme dan Radikalisme/Kekerasan jadi ancaman serius". Menurut Presiden SBY, bangsa Indonesia saat ini menghadapi ancaman serius terkait dengan terorisme, kekerasan horizontal, dan radikalisme yang terus terjadi di sejumlah tempat, jika tidak ditanggulangi secara serius, kondisi ini bisa berdampak pada harmoni kehidupan bangsa ke depan.

Ironisnya kasus-kasus kekerasan atas nama agama ini menjadikan mahasiswa sebagai sasaran utamanya. Hal ini terlihat dari munculnya kasus cuci otak NII pada mahasiswa di beberapa kampus, hingga kasus penculikan mahasiswa yang disinyalir dilakukan oleh gerakan NII KW IX yang terjadi pada pertengahan tahun 2010. Gerakan Negara Islam Indonesia (NII) yang diduga menjadi dalang dari kasus-kasus cuci otak dan radikalisme agama marak terjadi terutama di lingkungan kampus. Kasus ini menjadi 
kecemasan bagi kampus sebagai lingkungan yang kental dengan dunia pendidikan dan dakwah kampus.

Persepsi merupakan suatu proses yang didahului oleh penginderaan, yaitu proses diterimanya stimulus oleh individu melalui alat indera atau juga disebut proses sensoris. Persepsi berlangsung saat seseorang menerima stimulus dari dunia luar yang ditangkap oleh organ bantu yang masuk ke dalam otak. Dalam otak inilah terjadi proses berpikir dan akhirnya muncul dalam bentuk pemahaman. Pemahaman terhadap gerakan radikalisme belum tentu sama pada masing masing mahasiswa. Hal ini disebabkan, karena persepsi terhadap pemahaman radikalisme tergolong dalam persepsi sosial yang dipengaruhi oleh beragam faktor sosial. Objek persepsi yang diterima sama sekalipun dapat menimbulkan pemahaman dan penginterpretasian yang berbeda (Walgito, 2010). Dengan demikian yang dimaksud persepsi dalam penelitian ini adalah tanggapan atau pandangan mahasiswa terhadap gerakan radikalisme berbasis artinya tanggapan dan pandangan mahasiswa terhadap suatu paham keagamaan yang mengacu pada fondasi agama yang sangat mendasar dengan fanatisme keagamaan yang sangat tinggi, dengan menggunakan kekerasan untuk mengaktualisasikan paham keagamaan yang dianut dan diyakininya tersebut.

Masuknya paham dan gerakan Islam radikal di dunia kampus secara garis besar disebabkan dua faktor utama, yaitu faktor internal dan eksternal. Faktor internal mencakup faktor pemahaman agama dan psikologis. Sedangkan faktor eksternal meliputi faktor lingkungan akademis dan sosial, dan faktor ekonomi (Aryanti, Mustofa, Irwansyah, \& Walfajri, 2015). Berdasarkan studi pendahuluan yang dilakukan peneliti melalui tanya jawab dengan berbagai kalangan mahasiswa baik kalangan mahasiswa aktifis, mahasiswa rohis, maupun mahasiswa non aktif diperoleh beberapa data awal bahwa pada dasarnya mahasiswa yang rawan dimasuki berbagai ideologi radikal secara internal dipengaruhi oleh rendahnya pengetahuan agama yang dimilikinya. Artinya mahasiswa yang memiliki pengetahuan agama yang luas akan lebih bersifat terbuka dan lebih mudah menerima berbagai perbedaan.

Menurut (Rokhmad, 2012) bahwa salah satu faktor yang dapat mempengaruhi persepsi mahasiswa pada gerakan radikalisme berbasis agama adalah tingkat pengetahuan agama. Mahasiswa yang memiliki latar belakang pendidikan yang minim 
pengetahuan agamanya akan memberikan pandangan yang salah terhadap gerakan radikalisme berbasis agama tersebut.

Senada juga menurut (Aryanti et al., 2015) bahwa pengetahuan dan pemahaman agama yang rendah akan mengakibatkan pandangan yang sempit terhadap ajaran agama. Hal ini akan menimbulkan anggapan dirinya paling benar serta menimbulkan asumsi, bahwa pemahaman yang tidak sesuai dengan pemahaman mereka adalah salah dan sesat. Tidak berhenti di situ, keyakinan yang begitu kuat akan kebenaran diri dan kelompok juga dapat menimbulkan pemikiran penghalalan terhadap darah orang atau kelompok lain yang tidak sejalan

Menurut (Lai \& Zhang, 2013), pada dasarnya agama menjadi peran penting dalam memberikan konstribusi bagi layanan pendidikan inklusif bukan sebaliknya. Didukung oleh (Moadded \& Karabenick, 2008) yang menggambarkan bahwa masyarakat lebih mengandalkan otoritas keagamaan sebagai sumber pengetahuan tentang peran sosial politik dan berkehidupan sosial. Kedua pendapat tersebut menurut (Irham, 2015) dapat dipahami bahwa jika pemahaman keagamaan sempit dan eksklusif tidak menutup kemungkinan akan cenderung lebih tertutup dan tidak menerima keragaman.

Kemudian (Bano, 2010) menjelaskan bahwa pendidikan agama mampu bermitra dengan pemerintah untuk mewujudkan pendidikan yang terbuka dan saling menguatkan. Penguatan pendidikan agama dengan pendidikan sekuler bisa membentuk dan memelihata budaya dan identitas. Pendidikan agama juga berperan membangun siswa agar mampu bernegosiasi dengan perbedaan.

Sebagaimana yang dikemukakan (Azra, 2017) bahwa penguatan pemahaman keagamaan mahasiswa khususnya pada sikap keragaman agama, toleransi intraagama dan antaragama serta antara umat beragama dan negara sangat penting dilakukan untu mengantisipasi gerakan radikalisme dalam dunia kampus. Penelitian (Irham, 2015) juga menyatakan bahwa jika pemahaman keagamaan sempit dan eksklusif tidak menutup kemungkinan akan cenderung lebih tertutup dan tidak menerima keragaman.

Banyak sekali penelitian yang membahas mengenai gerakan radikalisme berbasis agama beberapa diantaranya gerakan radikalisme dalam islam: perspektif historis (Abdullah, 2016), membaca gerakan islam radikal dan deradikalisasi gerakan islam (Ahyar, 2015), gerakan radikalisme islam di Indonesia (Nuraida, 2011), 
radikalisme agama di Indonesia (ditinjau dari sudut pandang sosiologi Kewarganegaraan) (Mulyoto \& Mulyoto, 2017), melacak akar radikalisme islam di indonesia (Umar, 2010), radikalisme negara dan kekuasaan perspektif politik global (Ritaudin, 2014). Sudah pernah dilakukan juga penelitian mengenai persepsi dan resistensi aktivis muslim kampus terhadap paham dan gerakan islam radikal: kasus perguruan tinggi di Provinsi Lampung oleh (Aryanti et al., 2015).

Berdasarkan penelitian terdahulu dan uraian di atas dipahami bahwa tingkat pengetahuan agama yang dimiliki mahasiswa dapat mempengaruhi persepsi mereka terhadap gerakan radikalisme berbasis agama. Artinya semakin tinggi tingkat pengetahuan agama mahasiswa, maka persepsi mereka terhadap gerakan radikalisme berbasis agama semakin negatif, yang kemudian akan mengarah pada tingkat kecenderungan mereka terlibat pada gerakan radikalisme berbasis agama akan semain rendah atau kecil. Rumusan masalah dalam penelitian ini adalah seberapa besar pengaruh tingkat pengetahuan agama terhadap persepsi mahasiswa pada gerakan radikalisme berbasis agama?

\section{METODE PENELITIAN}

Jenis penelitian ini adalah penelitian survei dengan menggunakan metode penelitian kuantitatif. Menggunakan jenis penelitian survei karena dalam pengumpulan data, penulis menghimpun informasi dari para responden menggunakan kuesioner sebagai metode pokok. Sebagaimana yang dikemukakan (Singarimbun \& Effendi, 1989), metode penelitian kuantitatif digunakan karena penelitian kuantitaif bertujuan untuk mengetahui hubungan dua variabel atau lebih yang bersifat sebab akibat (kausal), menguji teori, dan analisa data dengan menggunakan statistik untuk menguji hipotesis (Sugiyono, 2016).

Variabel dalam penelitian ini ada dua yaitu: 1) variabel tingkat pengetahuan agama mahasiswa (X), dan 2) variabel persepsi mahasiswa terhadap gerakan radikalisme berbasis agama $(\mathrm{Y})$. Variabel $\mathrm{X}$ disebut dengan variabel independen (variabel bebas/yang mempengaruhi). Sedangkan variabel Y disebut dengan variabel dependen (variabel terikat/yang dipengaruhi).

Populasi dalam penelitian ini adalah seluruh individu yang berstatus sebagai mahasiswa Semester V di Universitas Islam Negeri Raden Intan Lampung Tahun 
Akademik 2017/2018 yang berjumlah 1900 orang. Pengambilan populasi diambil dari masing-masing fakultas sebanyak 2 program studi.

Sampel dalam penelitian ini ditentukan dengan menggunakan teknik random sampling, yaitu suatu cara dalam pengambilan sampel dengan cara acak tanpa memperhatikan strata yang ada dalam populasi (Sugiyono, 2016). Oleh karena itu dalam menentukan sampel dengan prosedur random sampling ini adalah melihat jumlah populasi secara menyeluruh kemudian menentukan sampel penelitian secara acak dari populasi yang menjadi obyek.

Berdasarkan perhitungan dengan menggunakan rumus dari Isaac dan Michael, diperoleh ukuran sampel baik pada taraf kesalahan 1\%, 5\% dan 10\% yang telah disusun dalam sebuah tabel penentuan jumlah sampel. Dengan menggunakan tabel tersebut, diketahui dari jumlah populasi sebanyak 1900 mahasiswa Universitas Islam Negeri Raden Intan Lampung Tahun Akademik 2017/2018, dengan menggunakan taraf kesalahan 5\%, dengan jumlah sampelnya adalah 295 mahasiswa Semester V di Universitas Islam Negeri Raden Intan Lampung Tahun Akademik 2017/2018.

Penelitian ini menggunakan beberapa teknik antara lain (1) kuesioner: digunakan untuk mengungkapkan tentang tingkat pengetahuan agama dan persepsi mahasiswa pada gerakan radikalisme berbasis agama, (2) wawancara: wawancara digunakan untuk memperoleh informasi secara langsung dengan dosen dan mahasiswa, (3) dokumentasi: digunakan untuk memperoleh data mengenai data mahasiswa, konsepkonsep teoritis yang dijadikan bahan kajian pustaka dan kerangka pikir, dalam bentuk buku-buku referensi dan lain-lain, (4) observasi, digunakan untuk mengamati perilaku keagamaan mahasiswa dan kegiatan keagamaan mahasiswa Universitas Islam Negeri Raden Intan Lampung.

Analisis regresi linier regresi sederhana digunakan untuk menguji hipotesis dalam penelitian ini. Analisis linier regresi sederhana digunakan untuk menelaah pengaruh antara dua variabel. Pengujian keberartian regresi sederhana dengan kriteria yang digunakan adalah apabila nilai $\mathrm{r}$ lebih besar dari nilai $\alpha$ tertentu maka Ho diterima. Sebaliknya apabila nilai $\mathrm{r}$ lebih kecil dari $(<)$ nilai $\alpha$ tertentu maka Ho ditolak. Untuk membantu perhitungan dalam menganalisis data dengan mempergunakan berbagai rumus tersebut, penulis menggunakan aplikasi program statistik SPSS 20.0. Program SPSS yang merupakan singkatan dari Statistical Product and Service 
Solutions, yaitu sebuah program aplikasi di komputer yang memiliki kemampuan analisis statistik cukup tinggi serta sistem manajemen data pada lingkungan grafis.

\section{HASIL PENELITIAN DAN PEMBAHASAN Hasil Uji Instrumen Penelitian}

Hasil uji coba validitas diketahui ada 3 (tiga) item kuesioner yang tidak valid yaitu item nomor 2, 22, dan 25 , karena karena nilai $\mathrm{r}_{\text {hitung }}$ lebih kecil dari nilai $\mathrm{r}_{\text {tabel }}$ dengan $\mathrm{df}=18$ yaitu 0,444 . Sehingga jumlah kuesioner tentang persepsi mahasiswa Universitas Islam Negeri Raden Intan Lampung pada gerakan radikalisme agama yang dapat digunakan dalam penelitian ini hanya 25 item kuesioner. Hasil uji coba validitas diketahui semua item kuesioner valid, karena nilai $\mathbf{r}_{\text {hitung }}$ semua item kuesioner lebih besar dari nilai $\mathrm{r}_{\text {tabel }}$ dengan $\mathrm{df}=18$ yaitu 0,444 . Sehingga jumlah kuesioner tentang pengetahuan agama mahasiswa yang dapat digunakan hanya 15 item kuesioner.

Hasil uji reliabilitas bahwa korelasi antara skor item dengan skor total item pada variabel persepsi mahasiswa pada gerakan radikalisme agama dan pengetahuan agama mahasiswa, diketahui pada taraf kesalahan 0,05 nilai $\mathbf{r}_{\text {hitung }}$ lebih besar dari pada $\mathrm{r}_{\text {tabel }}$ pada df $=18=(0.444)$. Artinya, butir-butir item pada variabel persepsi mahasiswa pada gerakan radikalisme agama dan pengetahuan agama mahasiswa reliabel dan dapat digunakan sebagai alat ukur yang sah atau benar dalam menghasilkan informasi mengenai persepsi mahasiswa pada gerakan radikalisme agama dan pengetahuan agama mahasiswa.

\section{Deskripsi Data Penelitian}

Berikut hasil analisis skor responden penelitian tentang persepsi mahasiswa Universitas Islam Negeri Raden Intan Lampung pada gerakan radikalisme agama diketahui tingkat persepsi mahasiswa Universitas Islam Negeri Raden Intan Lampung pada gerakan radikalisme agama sebagai berikut:

Tabel 1.1

Tingkat Persepsi Mahasiswa Universitas Islam Negeri Raden Intan Lampung Pada Gerakan Radikalisme Agama

\begin{tabular}{|c|l|c|c|}
\hline No & \multicolumn{1}{|c|}{$\begin{array}{c}\text { Persepsi Mahasiswa Pada Gerakan } \\
\text { Radikalisme Agama }\end{array}$} & Frekuensi & Persentase \\
\hline 1 & \multicolumn{1}{|c|}{ Sangat tidak setuju (109-127) } & 16 & 5,4 \\
\hline 2 & Tidak setuju $(90-108)$ & 75 & 25,4 \\
\hline
\end{tabular}




\begin{tabular}{|c|l|c|c|}
\hline 3 & Kurang setuju (71-89) & 145 & 49,2 \\
\hline 4 & Setuju (52-70) & 54 & 18,3 \\
\hline 5 & Sangat setuju (33-51) & 5 & 1,7 \\
\hline \multicolumn{2}{|c|}{ Jumlah } & 295 & $100 \%$ \\
\hline
\end{tabular}

Sumber: hasil pengolahan data melalui SPSS versi 20.0

Pada tabel tersebut, diketahui bahwa pada umumnya persepsi mahasiswa Universitas Islam Negeri Raden Intan Lampung pada gerakan radikalisme agama menunjukkan sikap kurang setuju yaitu sebanyak 49,2\%. Akan tetapi persentase mahasiswa yang menunjukkan sikap setuju pada gerakan radikalisme agama masih cukup banyak yaitu $18,3 \%$. Bahkan sebanyak $1,7 \%$ mahasiswa menyatakan sangat setuju pada gerakan radikalisme agama.

Data yang diperoleh pada tabel tersebut menunjukkan bahwa dari 295 responden penelitian, ada beberapa mahasiswa yang menyatakan setuju pada gerakan radikalime agama. Walaupun demikian pada umumnya mahasiswa di Universitas Islam Negeri Raden Intan Lampung menyatakan kurang dan tidak setuju akan gerakan radikalisme agama. Bahkan sebanyak 5,4\% mahasiswa menentang keras atau sangat tidak setuju akan gerakan radikalisme agama. Untuk lebih jelasnya dapat dilihat pada gambar berikut:

\section{Gambar 2.1}

Klasifikasi Persepsi Mahasiswa Universitas Islam Negeri Raden Intan Lampung Pada Gerakan Radikalisme Agama

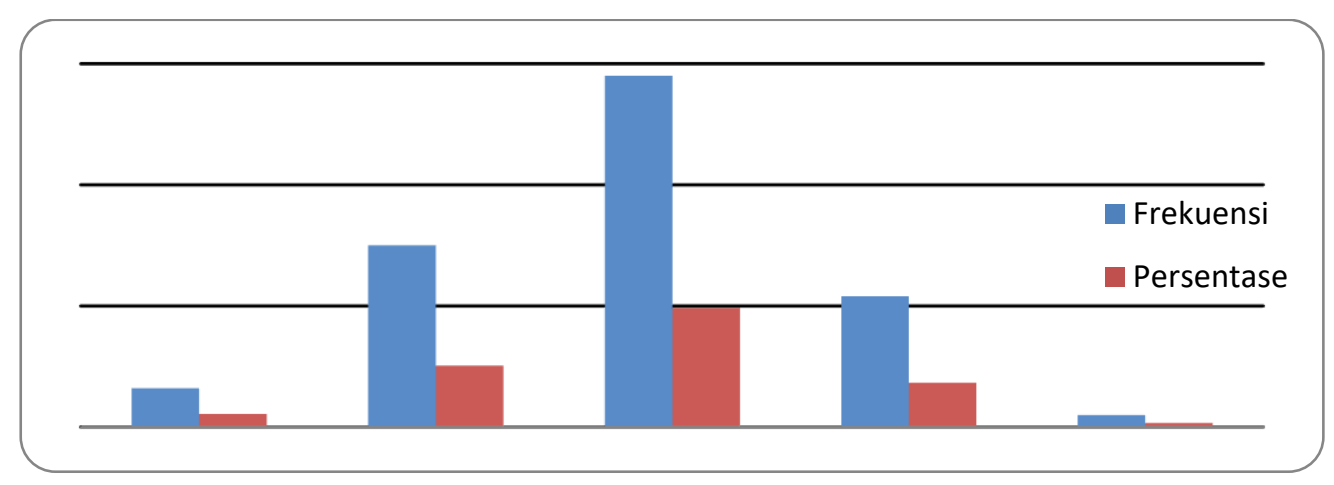

Apabila dilihat berdasarkan asal sekolah mahasiswa, maka persepsi mahasiswa Universitas Islam Negeri Raden Intan Lampung pada gerakan radikalisme agama dapat dilihat pada tabel berikut:

\section{Tabel 1.2}

Tingkat Persepsi Mahasiswa Universitas Islam Negeri Raden Intan Lampung Pada Gerakan Radikalisme Agama Berdasarkan Asal Sekolah 


\begin{tabular}{|l|c|c|c|c|c|}
\hline & $\begin{array}{c}\text { Sangat } \\
\text { tidak setuju }\end{array}$ & $\begin{array}{c}\text { Tidak } \\
\text { setuju }\end{array}$ & $\begin{array}{c}\text { Kurang } \\
\text { Setuju }\end{array}$ & Setuju & $\begin{array}{c}\text { Sangat } \\
\text { setuju }\end{array}$ \\
\hline MA & $4,1 \%$ & $28,9 \%$ & $48,5 \%$ & $17,5 \%$ & $1,0 \%$ \\
\hline SMA & $6,1 \%$ & $23,9 \%$ & $49,1 \%$ & $18,4 \%$ & $2,5 \%$ \\
\hline SMK & $8,7 \%$ & $26,1 \%$ & $43,5 \%$ & $21,7 \%$ & $0,0 \%$ \\
\hline PONPES & $0,0 \%$ & $16,7 \%$ & $66,7 \%$ & $16,7 \%$ & $0,0 \%$ \\
\hline
\end{tabular}

Sumber: hasil pengolahan data melalui SPSS versi 20.0

Pada tabel tersebut, diketahui bahwa dilihat dari asal sekolah, persepsi mahasiswa Universitas Islam Negeri Raden Intan Lampung pada gerakan radikalisme agama pada kategori sangat tidak setuju, lebih banyak dari mahasiswa dengan asal sekolah SMK yaitu sebanyak 8,7\%. Persepsi mahasiswa Universitas Islam Negeri Raden Intan Lampung pada gerakan radikalisme agama pada kategori tidak setuju, lebih banyak dari mahasiswa dengan asal sekolah SMK juga yaitu sebanyak 26,1\%. Persepsi mahasiswa Universitas Islam Negeri Raden Intan Lampung pada gerakan radikalisme agama pada kategori kurang setuju, lebih banyak dari mahasiswa dengan asal sekolah Pondok Pesantren sebanyak 66,7\%. Persepsi mahasiswa Universitas Islam Negeri Raden Intan Lampung pada gerakan radikalisme agama pada kategori setuju, lebih banyak dari mahasiswa dengan asal sekolah SMK sebanyak 21,7\%. Persepsi mahasiswa Universitas Islam Negeri Raden Intan Lampung pada gerakan radikalisme agama pada kategori sangat setuju, lebih banyak dari mahasiswa dengan asal sekolah SMA sebanyak $2,5 \%$.

Apabila dilihat berdasarkan asal fakultas mahasiswa, maka persepsi mahasiswa Universitas Islam Negeri Raden Intan Lampung pada gerakan radikalisme agama dapat dilihat pada tabel berikut:

\section{Tabel 1.3}

Tingkat Persepsi Mahasiswa Universitas Islam Negeri Raden Intan Lampung Pada Gerakan Radikalisme Agama Berdasarkan Fakultas

\begin{tabular}{|l|c|c|c|c|c|}
\hline \multirow{2}{*}{ Fakultas } & \multicolumn{5}{|c|}{ Persepsi Mahasiswa Pada Gerakan Radikalisme Agama } \\
\cline { 2 - 6 } & $\begin{array}{c}\text { Sangat } \\
\text { tidak setuju }\end{array}$ & $\begin{array}{c}\text { Tidak } \\
\text { setuju }\end{array}$ & $\begin{array}{c}\text { Kurang } \\
\text { Setuju }\end{array}$ & Setuju & $\begin{array}{c}\text { Sangat } \\
\text { setuju }\end{array}$ \\
\hline TARBIYAH & $9,9 \%$ & $17,6 \%$ & $50,4 \%$ & $20,6 \%$ & $1,5 \%$ \\
\hline SYARIAH & $3,1 \%$ & $29,7 \%$ & $46,9 \%$ & $17,2 \%$ & $3,1 \%$ \\
\hline USHULUDDIN & $0,0 \%$ & $50,0 \%$ & $40,0 \%$ & $10,0 \%$ & $0,0 \%$ \\
\hline FEBI & $3,1 \%$ & $46,9 \%$ & $40,6 \%$ & $6,2 \%$ & $3,1 \%$ \\
\hline DAKWAH & $0,0 \%$ & $16,7 \%$ & $58,3 \%$ & $25,0 \%$ & $0,0 \%$ \\
\hline
\end{tabular}

Sumber: hasil pengolahan data melalui SPSS versi 20.0 
Pada tabel tersebut, diketahui bahwa dilihat dari asal fakultas, persepsi mahasiswa Universitas Islam Negeri Raden Intan Lampung pada gerakan radikalisme agama pada kategori sangat tidak setuju, lebih banyak dari mahasiswa dengan asal Fakultas Tarbiyah yaitu sebanyak 9,9\%, Persepsi mahasiswa Universitas Islam Negeri Raden Intan Lampung pada gerakan radikalisme agama pada kategori tidak setuju, lebih banyak dari mahasiswa dengan asal fakultas Ushuluddin yaitu sebanyak 50\%. Persepsi mahasiswa Universitas Islam Negeri Raden Intan Lampung pada gerakan radikalisme agama pada kategori kurang setuju, lebih banyak dari mahasiswa dengan asal fakultas Tarbiyah sebanyak 50,4\%. Persepsi mahasiswa Universitas Islam Negeri Raden Intan Lampung pada gerakan radikalisme agama pada kategori setuju, lebih banyak dari mahasiswa dengan asal fakultas Dakwah sebanyak 25\%. Persepsi mahasiswa Universitas Islam Negeri Raden Intan Lampung pada gerakan radikalisme agama pada kategori sangat setuju, lebih banyak dari mahasiswa dengan asal fakultas Syariah dan fakultas Ekonomi dan Bisnis sebanyak 3,1\%.

Apabila dilihat berdasarkan jenis kelamin mahasiswa, maka persepsi mahasiswa Universitas Islam Negeri Raden Intan Lampung pada gerakan radikalisme agama dapat dilihat pada tabel berikut:

Tabel 1.4

Tingkat Persepsi Mahasiswa Universitas Islam Negeri Raden Intan Lampung Pada Gerakan Radikalisme Agama Berdasarkan Jenis Kelamin

\begin{tabular}{|l|c|c|c|c|c|}
\hline \multirow{2}{*}{ Jenis Kelamin } & \multicolumn{4}{|c|}{ Persepsi Mahasiswa Pada Gerakan Radikalisme Agama } \\
\cline { 2 - 6 } & $\begin{array}{c}\text { Sangat } \\
\text { tidak } \\
\text { setuju }\end{array}$ & $\begin{array}{c}\text { Tidak } \\
\text { setuju }\end{array}$ & $\begin{array}{c}\text { Kurang } \\
\text { Setuju }\end{array}$ & Setuju & $\begin{array}{c}\text { Sangat } \\
\text { setuju }\end{array}$ \\
\hline Laki-Laki & $5,7 \%$ & $29,2 \%$ & $45,3 \%$ & $17,0 \%$ & $2,8 \%$ \\
\hline Perempuan & $5,3 \%$ & $23,3 \%$ & $51,3 \%$ & $19,0 \%$ & $1,1 \%$ \\
\hline
\end{tabular}

Sumber: hasil pengolahan data melalui SPSS versi 20.0

Pada tabel tersebut, diketahui bahwa dilihat dari jenis kelamin mahasiswa, persepsi mahasiswa Universitas Islam Negeri Raden Intan Lampung pada gerakan radikalisme agama pada kategori sangat tidak setuju, lebih banyak dari mahasiswa dengan jenis kelamin laki-laki sebanyak 5,7\%. Persepsi mahasiswa Universitas Islam Negeri Raden Intan Lampung pada gerakan radikalisme agama pada kategori tidak 
setuju, lebih banyak dari mahasiswa dengan jenis kelamin laki-laki sebanyak 29,2\%. Persepsi mahasiswa Universitas Islam Negeri Raden Intan Lampung pada gerakan radikalisme agama pada kategori kurang setuju, lebih banyak dari mahasiswa dengan jenis kelamin perempuan sebanyak 51,3\%. Persepsi mahasiswa Universitas Islam Negeri Raden Intan Lampung pada gerakan radikalisme agama pada kategori setuju, lebih banyak dari mahasiswa dengan jenis kelamin perempuan sebanyak 19\%. Persepsi mahasiswa Universitas Islam Negeri Raden Intan Lampung pada gerakan radikalisme agama pada kategori sangat setuju, lebih banyak dari mahasiswa dengan jenis kelamin laki-laki sebanyak $2,8 \%$.

Berdasarkan hasil analisis angket jawaban responden penelitian, tentang persepsi mahasiswa Universitas Islam Negeri Raden Intan Lampung pada gerakan radikalisme agama, diperoleh data bahwa pada umumnya persepsi mahasiswa Universitas Islam Negeri Raden Intan Lampung pada gerakan radikalisme agama berada pada kategori kurang setuju. Hal tersebut mengindikasikan bahwa persepsi mahasiswa Universitas Islam Negeri Raden Intan Lampung pada gerakan radikalisme agama masih perlu diberikan pembinaan, agar persepsi mahasiswa Universitas Islam Negeri Raden Intan Lampung pada gerakan radikalisme agama menolak gerakan radikalisme agama tersebut.

Berikut hasil analisis skor responden penelitian tentang pengetahuan agama mahasiswa di Universitas Islam Negeri Raden Intan Lampung tersebut:

\section{Tabel 1.5}

Tingkat Pengetahuan Agama Mahasiswa di Universitas Islam Negeri Raden Intan Lampung

\begin{tabular}{|c|l|c|c|}
\hline No & \multicolumn{1}{|c|}{ Pengetahuan Agama Mahasiswa } & Frekuensi & Persentase \\
\hline 1 & Tinggi (56-70) & 172 & 58,3 \\
\hline 2 & Sedang (41-55) & 111 & 37,6 \\
\hline 3 & Rendah (25-40) & 12 & 4,1 \\
\hline \multicolumn{2}{|c|}{ Jumlah } & 295 & $100 \%$ \\
\hline
\end{tabular}

Sumber: hasil pengolahan data melalui SPSS versi 20.0

Pada tabel tersebut, diketahui bahwa pada umumnya pengetahuan agama mahasiswa di Universitas Islam Negeri Raden Intan Lampung pada ketageori tinggi yaitu sebanyak 58,3\%. Sedangkan tingkat pengetahuan agama mahasiswa di Universitas Islam Negeri Raden Intan Lampung yang dikategorikan rendah hanya 4,1\%. Untuk lebih jelasnya dapat dilihat pada gambar berikut:

\section{Gambar 2.2}


Klasifikasi Pengetahuan Agama Mahasiswa di Universitas Islam Negeri Raden Intan Lampung

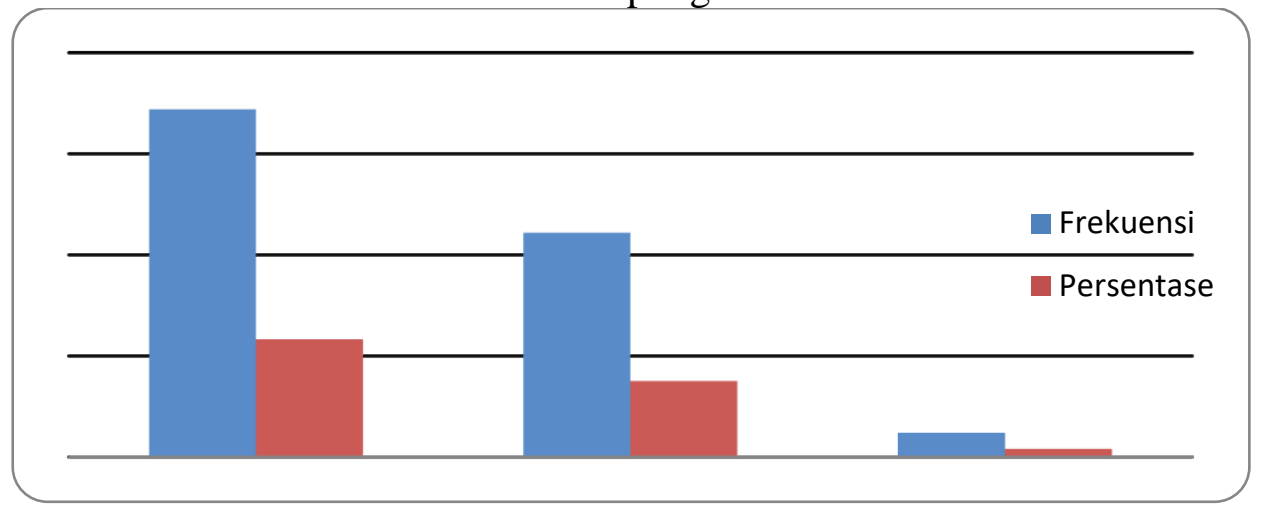

Berdasarkan hasil analisis angket jawaban responden penelitian, tentang pengetahuan agama mahasiswa di Universitas Islam Negeri Raden Intan Lampung, diperoleh data bahwa pada umumnya pengetahuan agama mahasiswa di Universitas Islam Negeri Raden Intan Lampung berada pada kategori tinggi. Hal tersebut mengindikasikan bahwa pengetahuan agama mahasiswa di Universitas Islam Negeri Raden Intan Lampung sudah optimal.

\section{Hasil Uji Hipotesis}

Hipotesis yang diuji kebenarannya dalam penelitian ini adalah "Tingkat pengetahuan agama memiliki pengaruh yang signifikan terhadap persepsi mahasiswa pada gerakan radikalisme berbasis agama." Pengujian hipotesis menggunakan uji statistik regresi sederhana untuk menelaah pengaruh pengetahuan agama terhadap persepsi mahasiswa pada gerakan radikalisme berbasis agama.

Hasil perhitungan persamaan regresi linier sederhana pengaruh pengetahuan agama terhadap persepsi mahasiswa Universitas Islam Negeri Raden Intan Lampung pada gerakan radikalisme berbasis agama diperoleh harga keofisien arah regresi sebesar 0,033 dan persamaan regresinya adalah $Y_{1}=a+b x=80,687+(10,033 X)$. Berikut hasil perhitungannya:

\section{Tabel 1.6}

Koefisien Regresi Pengaruh Pengetahuan Agama terhadap Persepsi Mahasiswa Pada Gerakan Radikalisme Berbasis Agama

\begin{tabular}{|c|l|c|c|c|c|c|}
\hline \multicolumn{8}{|c|}{ Coefficients $^{\mathrm{a}}$} \\
\hline \multirow{2}{*}{ Model } & \multicolumn{2}{|c|}{$\begin{array}{c}\text { Unstandardized } \\
\text { Coefficients }\end{array}$} & $\begin{array}{c}\text { Standardized } \\
\text { Coefficients }\end{array}$ & $\mathrm{t}$ & Sig. \\
\cline { 3 - 8 } & $\mathrm{B}$ & Std. Error & Beta & & \\
\hline \multirow{2}{*}{1} & (Constant) & 80,687 & 6,567 & & 12,287 & 0,000 \\
\cline { 2 - 5 } & Pengetahuan Agama & 0,033 & 0,116 & 0,017 & 0,288 & 0,774 \\
\hline
\end{tabular}


a. Dependent Variable: Persepsi Mahasiswa Pada Radikalime

Sumber: hasil pengolahan data melalui SPSS versi 20

Hasil perhitungan regresi linier sederhana pengaruh pengetahuan agama terhadap persepsi mahasiswa Universitas Islam Negeri Raden Intan Lampung pada gerakan radikalisme berbasis agama tersebut, kemudian dilakukan pengujian signifikannya dengan mengaplikasikan analisis varians. Berikut hasil pengujian keberartian regresi pengaruh pengetahuan agama terhadap persepsi mahasiswa Universitas Islam Negeri Raden Intan Lampung pada gerakan radikalisme berbasis agama:

Tabel 1.7

Pengujian Keberartian Regresi Pengaruh Pengetahuan Agama terhadap Persepsi Mahasiswa Pada Gerakan Radikalisme Berbasis Agama

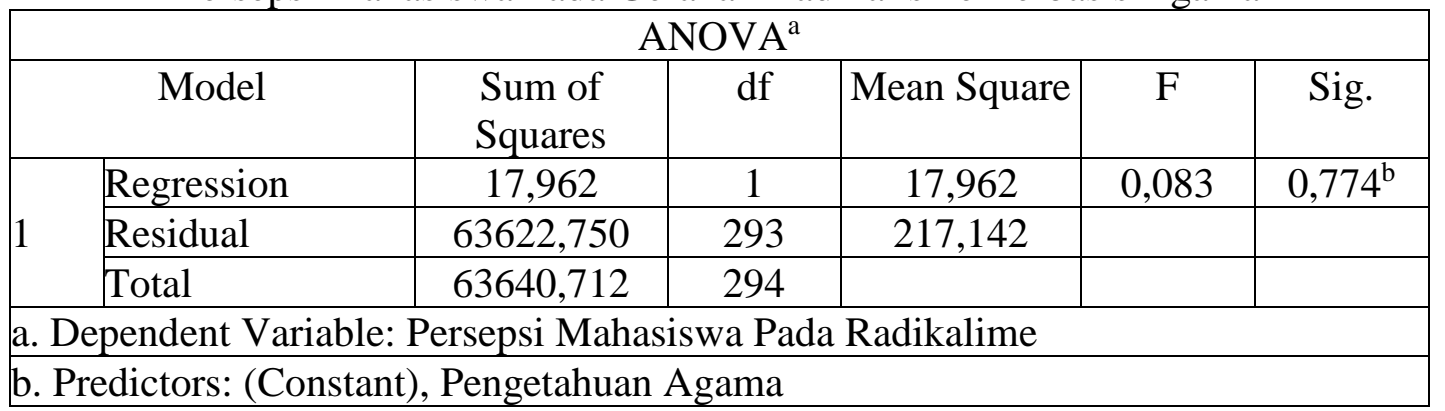

Sumber: hasil pengolahan data melalui SPSS versi 20

Berdasarkan hasil perhitungan pengujian keberartian regresi pengaruh pengetahuan agama terhadap persepsi mahasiswa Universitas Islam Negeri Raden Intan Lampung pada gerakan radikalisme berbasis agama pada tabel 4.14, diketahui bahwa nilai $\rho$ lebih besar dari pada tingkat $\alpha$ yang digunakan (yaitu 0,05 ) atau $0,774>0,05$ sehingga hipotesis dalam penelitian ini ditolak atau tidak diterima. Dengan demikian dapat diartikan bahwa tidak ada pengaruh pengetahuan agama terhadap persepsi mahasiswa Universitas Islam Negeri Raden Intan Lampung pada gerakan radikalisme berbasis agama.

Hal ini mengindikasikan bahwa model persamaan $Y_{1}=a+b x=80,687+(10,033 X)$ tidak signifikan dan tidak dapat menjelaskan arah kekuatan pengaruh pengetahuan agama terhadap persepsi mahasiswa Universitas Islam Negeri Raden Intan Lampung pada gerakan radikalisme berbasis agama. Atau dengan kata lain berdasarkan persamaan regresi tersebut diketahui bahwa antara variabel pengetahuan agama dan persepsi mahasiswa Universitas Islam Negeri Raden Intan 
Lampung pada gerakan radikalisme berbasis agama tidak terdapat pengaruh yang signifikan.

Besarnya pengaruh pengetahuan agama terhadap persepsi mahasiswa Universitas Islam Negeri Raden Intan Lampung pada gerakan radikalisme berbasis agama dapat dilihat pada hasil perhitungan sebagai berikut:

Tabel 1.8

Besarnya Pengaruh Pengetahuan Agama terhadap Persepsi Mahasiswa Pada Gerakan Radikalisme Berbasis Agama

\begin{tabular}{|l|r|r|r|r|}
\hline \multicolumn{5}{|c|}{ Model Summary $^{\mathbf{b}}$} \\
\hline 1 & $\mathrm{R}$ & R Square & Adjusted R Square & $\begin{array}{c}\text { Std. Error of the } \\
\text { Estimate }\end{array}$ \\
\hline & $0,017^{\mathrm{a}}$ & 0,000 &,- 003 & 14,736 \\
\hline \\
a. Predictors: (Constant), Pengetahuan Agama \\
\hline
\end{tabular}

Sumber: hasil pengolahan data melalui SPSS versi 20

Pada tabel tersebut, diketahui pengaruh pengetahuan agama terhadap persepsi mahasiswa Universitas Islam Negeri Raden Intan Lampung pada gerakan radikalisme berbasis agama sebesar 0,017 atau dapat dikatakan persepsi mahasiswa Universitas Islam Negeri Raden Intan Lampung pada gerakan radikalisme berbasis agama dipengaruhi oleh variabel pengetahuan agama sebesar 1,7\% yang dikategorikan pengaruhnya sangat lemah.

Berdasarkan hasil pengujian di atas, disimpulkan bahwa pengetahuan agama tidak terbukti signifikan dalam mempengaruhi persepsi mahasiswa Universitas Islam Negeri Raden Intan Lampung pada gerakan radikalisme berbasis agama, sehingga hipotesis yang berbunyi "Tingkat pengetahuan agama memiliki pengaruh yang signifikan terhadap persepsi mahasiswa pada gerakan radikalisme berbasis agama" tidak dapat teruji kebenarannya. Artinya pengaruh pengetahuan agama terhadap persepsi mahasiswa Universitas Islam Negeri Raden Intan Lampung pada gerakan radikalisme berbasis agama sangat lemah.

Pengaruh pengetahuan agama terhadap persepsi mahasiswa Universitas Islam Negeri Raden Intan Lampung pada gerakan radikalisme berbasis agama sebesar 0,017 atau dapat dikatakan persepsi mahasiswa Universitas Islam Negeri Raden Intan 
Lampung pada gerakan radikalisme berbasis agama dipengaruhi oleh variabel pengetahuan agama sebesar 1,7\% yang dikategorikan pengaruhnya sangat lemah.

Berdasarkan hasil perhitungan pengujian keberartian regresi pengaruh pengetahuan agama terhadap persepsi mahasiswa Universitas Islam Negeri Raden Intan Lampung pada gerakan radikalisme berbasis agama pada tabel 4.14, diketahui bahwa nilai $\rho$ lebih besar dari pada tingkat $\alpha$ yang digunakan (yaitu 0,05 ) atau $0,774>0,05$ sehingga hipotesis dalam penelitian ini ditolak atau tidak diterima. Dengan demikian dapat diartikan bahwa tidak ada pengaruh pengetahuan agama terhadap persepsi mahasiswa Universitas Islam Negeri Raden Intan Lampung pada gerakan radikalisme berbasis agama.

Temuan penelitian tersebut menjelaskan bahwa tingkat pengetahuan agama yang dimiliki mahasiswa sangat lemah dalam mempengaruhi persepsi mahasiswa Universitas Islam Negeri Raden Intan Lampung pada gerakan radikalisme agama. Artinya tingginya tingkat pengetahuan agama mahasiswa bukan menjadi patokan bahwa mahasiswa akan memberikan persepsi negatif atau tidak setuju pada gerakan radikalisme agama. Begitu juga sebaliknya tingkat pengetahuan agama mahasiswa yang rendah, tidak menjadi patokan bahwa mahasiswa tersebut akan memberikan persepsi positif terhadap gerakan radikalisme agama.

Temuan penelitian ini berbeda dengan pendapat (Rokhmad, 2012) yang menyatakan bahwa salah satu faktor yang mempengaruhi persepsi siswa terhadap gerakan radikalisme berbasis agama adalah tingkat pengetahuan agama. Berdasarkan pendapat Abu Rokhmad tersebut seharusnya pengetahuan agama yang dimiliki seseorang akan menjadi landasan bagi seorang muslim untuk menolak gerakan radikalisme dalam agama.

Hasil penelitian ini menemukan suatu perbedaan bahwa tingkat pengetahuan agama mahasiswa memiliki pengaruh yang lemah terhadap persepsinya pada gerakan radikalisme agama. Untuk itu perlu dilakukan kajian lebih lanjut mengenai pengetahuan agama yang dimiliki mahasiswa tersebut. Karena dimungkinkan pengetahuan agama yang dimiliki mahasiswa tersebut bersifat sempit dan ekslusif, sehingga memahami agama tidak bersifat terbuka. Sebagaimana yang dikemukakan (Irham, 2015) bahwa jika pemahaman keagamaan sempit dan eksklusif tidak menutup kemungkinan akan cenderung lebih tertutup dan tidak menerima keragaman. 
Sebagai salah satu contoh dalam agama Islam ada pemahaman amar ma'ruf nahi mungkar. Konsep amar ma'ruf nahi munkar juga bisa mendatangkan pemahaman keliru sehingga mengidentikkannya dengan kekerasan. Hadis yang terkenal mengenai nahi munkar adalah: "Barangsiapa di antara kamu melihat kemungkaran maka tegahlah dengan tangan, kalau ia tidak sanggup (berbuat demikian), maka hendaklah ia mengubah dengan lisannya, dan kalau tidak sanggup (pula), maka hendaklah ia melakukan dengan hatinya (mendo'akan), yang demikian adalah selemah-lemah iman." (H.R. Ahad bin Hanbal, Muslim dan Ashab as-Sunan (para ahli hadis penyusun kitab hadis Sunan).

Jika hadis ini dipahami secara tekstual, maka cara nahi mungkar yang utama adalah dengan cara kekerasan, yaitu dengan tangan. Tetapi tidak semua hadis, termasuk ayat, dapat dipahami secara tekstual. Adakalanya yang tertulis mesti dipahami secara kontekstual. Mencegah dengan tangan tersebut bukanlah dimaknai dengan kekerasan, tetapi dengan kekuasaan. Artinya mencegah kemungkaran dengan kekuasaan yang dimiliki. Seorang pemimpin harus mencegah bawahannya dari perilaku kemungkaran, sebab dia berkuasa atas bawahannya; orang tua harus mencegah anaknya dari kemungkaran, sebab orang tua juga berkuasa atas anaknya; seorang suami juga mesti mencegah istrinya berbuat kemungkaran sebab suami berkuasa atas istrinya; begitu seterusnya.

Berdasarkan contoh tersebut, apabila pengetahuan agama mahasiswa bersifat sebagaimana contoh di atas yaitu memahami semua konteks ayat ataupun hadis secara tekstual, maka sedalam apapun pengetahuan agamanya, maka persepsinya pada gerakan radikalisme agama cenderung lebih positif atau setuju. Untuk itu dalam memberikan pengetahuan agama kepada siswa maupun mahasiswa tidak hanya sampai pada tahap siswa dan mahasiswa mengetahui berbagai ajaran agama. Akan tetapi juga mampu memahami, menganalisis, mengevaluasi, dan merekontruksi ajaran agamanya dengan lebih luas dan mendalam, sehingga implementasi dari ajaran agamanya dapat dilaksanakan dengan tepat dalam kehidupan beragama baik sebagai manusia pribadi maupun sosial.

Temuan penelitian ini juga mengindikasikan perlunya perbaikan sistem pendidikan agama Islam, baik pada tujuan, materi, strategi pembelajaran, evaluasi, maupun guru dan dosen agama Islamnya. Pendidikan agama Islam di sekolah maupun 
di perguruan tinggi hendaknya menyajikan materi pendidikan agama Islam dengan tidak hanya dalam satu pandangan mazhab saja. Begitu juga guru dan dosen agama Islam sebagai penyaji materi, hendaknya menyampaikan materi agama Islam dengan lebih luas dan mendalam, sehingga wawasan keislaman siswa dan mahasiswa tidak memandang agama hanya pada satu sisi saja yang membuat siswa dan mahasiswa keliru dalam memahami ajaran agama, yang selanjutnya akan membawa pada pemahaman yang radikal.

Sebagaimana hasil penelitian (Abdullah, 2016) bahwa perlu dilakukan usaha intensif oleh kalangan muballigh, ulama, tokoh agama, guru agama, dosen agama, para Kiyai di Pondok Pesantren untuk melakukan sosialisasi penafsiran secara murni dan tuntas berdasarkan metodologi tafsir ilmiah. Hal ini dilakukan untuk memberikan pengetahuan dan pemahaman yang benar kepada para peserta didik, pelajar, mahasiswa, dan kalangan santri agar tidak terjebak dalam kesalahan menafsirkan ayat-ayat yang terkait dengan istilah "jihad". Karena dalam Islam tidak mengenal cara-cara kekerasan dalam mencapai tujuan. Perdamaian merupakan sesuatu yang mendasar, dan setiap Muslim wajib mengusahakannya. Jihad yang benar adalah berjuang dengan segala tenaga, pemikiran, dan mental untuk mewujudkan perdamaian dan keadilan di tengahtengah masyarakat. Tidak benar, bahwa Islam adalah agama kekerasan dan agama radikal. Pandangan dan tindakan radikal atas nama Tuhan dalam Islam sangat bertolak belakang dengan konsep "rahmatanlilalamin".

\section{SIMPULAN DAN SARAN}

Berdasarkan hasil analisis data, diperoleh kesimpulan hasil penelitian sesuai dengan masalah yang telah dirumuskan yaitu hipotesis penelitian tidak diterima, sehingga tingkat pengetahuan agama tidak memiliki pengaruh yang signifikan terhadap persepsi mahasiswa pada gerakan radikalisme berbasis agama. Besarnya pengaruh pengetahuan agama terhadap persepsi mahasiswa pada gerakan radikalisme berbasis agama hanya $1,7 \%$ yang dikategorikan pengaruhnya sangat lemah. 


\section{DAFTAR PUSTAKA}

Abdullah, A. (2016). Gerakan Radikalisme Dalam Islam: Perspektif Historis. Addin, $10(1)$.

Ahyar, M. (2015). Membaca Gerakan Islam Radikal dan Deradikalisasi Gerakan Islam. Walisongo, 23(1), 1-26.

Aryanti, Z., Mustofa, I., Irwansyah, D., \& Walfajri. (2015). Persepsi Dan Resistensi Aktivis Muslim Kampus Terhadap Paham dan Gerakan Islam Radikal: Kasus Perguruantinggi di Provinsi Lampun. Jurnal PENAMAS, 28(2).

Azra, A. (1999). Menuju Masyarakat Madani: Gagasan, Fakta dan Tantangan. Bandung: PT Remaja Rosda Karya.

Azra, A. (2017). Rekrutmen Sel Radikal di Kampus.

Bano, M. (2010). Madrasas as Patners in Education Provision: The South Asian Experience dalam, Volume 20 Nomor 4/5, Tahun 2010. Journal Development in Practice, 20(4/5).

Crawford, B. (2001). Politik Identitas: Sebuah Pendekatan Kelembagaan. Urnal Gerbang, 10(IV).

Irham. (2015). Pesantren dan Perkembangan Politik Pendidikan Agama di Indonesia. Jurnal Pendidikan Agama Islam Ta'lim Universitas Pendidikan Indonesia, 13(1).

Lai, Y. S. S., \& Zhang, K. C. (2013). A Comparison in Inclusive Practices for Children with Special Needs in Faith-Based Kindergartens in Hong Kong,. Journal Relig Health, 53.

Moadded, M., \& Karabenick, S. A. (2008). Relegious Fundamentalism among Youg Muslim Agyp and Saudi Arabia. Journal Social Forces, 86(4).

Mulyoto, G. P., \& Mulyoto, G. P. (2017). Radikalisme Agama Di Indonesia (Ditinjau dari Sudut Pandang Sosiologi Kewarganegaraan). Citizenship Jurnal Pendidikan Pancasila Dan Kewarganegaraan, 5(1), 64-74.

Nadia, Z. (2012). Akar-akar Radikalisme Islam dalam Tafsir Fi Zilal al-Qur'an Karya Sayyid Quth. Mukaddimah, 18(2).

Nuraida. (2011). Gerakan Radikalisme Islam di Indonesia, 153-162.

Ritaudin, M. S. (2014). Radikalisme Negara Dan Kekuasaan Perspektif Politik Global. Kalam: Jurnal Studi Agama Dan Pemikiran Islam, 8(2), 389-414.

Rokhmad, A. (2012). Radikalisme Islam dan Upaya Deradikalisasi Paham Radikal. Jurnal Walisongo Universitas Diponegoro Semarang, 20(1).

Singarimbun, M., \& Effendi, S. (1989). Metode Penelitian Survai. Jakarta: LP3ES.

Sugiyono. (2016). Metode Penelitian Pendidikan (Pendekatan Kuantitatif, Kualitatif, dan $R \& D)$. Bandung: Alfabeta. 
Umar, A. R. M. (2010). Melacak Akar Radikalisme Islam di Indonesia. Jurnal Ilmu Sosial Dan Ilmu Politik, 14(2), 169-186.

Walgito, B. (2010). Pengantar Psikologi Umum. Yogyakarta: Andi Offset.

Wilner, A., \& Dubouloz, C.-J. (2009). Homegrown Terrorism and Transformative Learning: An Interdisciplinary Approach to Understanding Radicalization. Ottawa: Canadian Political Science Association Conference. 